\title{
Analiza aktualnego stanu zasobów gazu ziemnego znajdujących się w złożach krajowych oraz prognoza krajowego wydobycia gazu do roku 2030
}

\author{
Analysis of the current state of natural gas resources in domestic deposits and a forecast \\ of domestic gas production until 2030
}

\author{
Wacława Piesik-Buś, Bogdan Filar \\ Instytut Nafty i Gazu - Państwowy Instytut Badawczy
}

\begin{abstract}
STRESZCZENIE: Gaz ziemny jest podstawowym paliwem energetycznym w gospodarce światowej. Zgodnie z informacją opublikowaną przez Polskie Górnictwo Naftowe i Gazownictwo SA w dokumencie Prezentacja Spółki - zużycie gazu w 2018 roku wyniosło 19,7 mld m³. W związku z tym, że stopień czerpania krajowych złóż gazu ziemnego jest coraz większy, zapotrzebowanie na gaz ziemny będzie zaspokajane przez rosnący import. Bilansowanie krajowego zapotrzebowania na gaz będzie wymagało precyzyjnej znajomości wielkości krajowej produkcji gazu ziemnego. Z drugiej strony Państwowy Instytut Geologiczny - Państwowy Instytut Badawczy co roku publikuje Bilans zasobów złóż kopalin w Polsce. Zgodnie z publikacją dotyczącą stanu zasobów na dzień 31.12 .2018 r. w Polsce udokumentowano 298 złóż gazu ziemnego, na Bałtyku - 5, w Karpatach - 35, na przedgórzu Karpat (dalej: Przedgórze) - 105 oraz na Niżu Polskim (dalej: Niż) - 153. Bilans przedstawiony przez PIG - BIP za rok 2018 wykazał stan wydobywalnych zasobów gazu ziemnego w wielkości 139,93 mld m³ (łącznie zasoby bilansowe i pozabilansowe). Wielkość zasobów przemysłowych złóż gazu ziemnego na dzień 31.12.2018 r. wyniosła 66,64 mld $\mathrm{m}^{3}$. Należy podkreślić, że wszystkie dane w Bilansie zasobów złóż $i$ kopalin w Polsce podawane są w normalnych metrach sześciennych. W związku z tym dane publikowane przez PIG - BIP nie uwzględniają rzeczywistej kaloryczności gazu ziemnego wydobywanego z różnych złóż. Począwszy od roku 2014 w Polsce podstawową jednostką rozliczeniową jest jednostka energii $(\mathrm{kWh})$. Wprowadzenie rozliczenia w jednostkach energii spowodowało, że wartość $1 \mathrm{~m}^{3}$ gazu zaazotowanego wydobywanego ze złóż znajdujących się na Niżu jest niższa od wartości gazu wydobywanego ze złóż Przedgórza i Karpat. Średnia kaloryczność gazu wydobywanego ze złóż Niżu wynosi około $8,0 \mathrm{kWh} / \mathrm{m}^{3}$, natomiast ze złóż Przedgórza - 11,2 kWh $/ \mathrm{m}^{3}$. Głównym celem niniejszej pracy było wykonanie prognozy wydobycia gazu ze złóż krajowych na podstawie publikowanego przez PIG - BIP Bilansu zasobów złóż kopalin w Polsce. Prognozę wydobycia gazu z krajowych złóż przygotowano dla lat 2020-2030, dla każdego rejonu gazonośnego oddzielnie. W celu dostosowania wielkości raportowanych do obowiązujących jednostek energii prognoza wydobycia gazu wykonana dla złóż obszaru Niżu została przeliczona na wydobycie gazu wysokometanowego.
\end{abstract}

Słowa kluczowe: gaz ziemny, wydobycie gazu, zasoby gazu, prognoza, złoża gazu.

Natural gas is the basic fossil fuel in the global economy. According to the information published by Polskie Górnictwo Naftowe i Gazownictwo SA in the document Company Presentation, gas consumption in 2018 amounted to 19.7 billion $\mathrm{m}^{3}$. Due to the fact that the domestic reserves of natural gas are increasingly depleted, the demand for natural gas will be satisfied by growing imports. Balancing gas demand will require precise knowledge of the volume of domestic natural gas production. On the other hand, every year the Polish Geological Institute - National Research Institute (PIG - BIP) publishes Balance of mine resources in Poland. According to the publication on the state of resources as of December 31, 2018, 298 natural gas fields have been documented in Poland, 5 in the Baltic Sea region, 35 in Carpathians, 105 in Carpathian Foreland and 153 in Polish Lowland. The balance presented by PIG - BIP for 2018 showed the state of natural gas contingent resources in the amount of 139.93 billion $\mathrm{m}^{3}$ (total balance resources). The volume of industrial reserves of natural gas deposits as at December 31, 2018 was 66.64 billion $\mathrm{m}^{3}$. It should be emphasized that all data published in the Balance of mine resources in Poland are given in normal cubic meters. Therefore, the data published by PIG - BIP do not take into account the actual calorific value of natural gas produced from various fields. Starting from 2014, the basic accounting unit in Poland is the energy unit $(\mathrm{kWh})$. Due to the introduction of the settlement in energy units, the value of $1 \mathrm{~m}^{3}$ of nitrogen-rich gas produced from the fields located in the Lowland region is lower than the value of gas produced from the Carpathian Foreland fields and

Autor do korespondencji: W. Piesik-Buś, e-mail: waclawa.piesik@inig.pl

Artykuł nadesłano do Redakcji: 15.01.2021 r. Zatwierdzono do druku: 07.06.2021 r. 
the Carpathians. The average calorific value of gas produced from the Lowland fields is about $8.0 \mathrm{kWh} / \mathrm{m}^{3}$, while the average calorific value of gas produced from the rest of the Foreland is about $11.2 \mathrm{kWh} / \mathrm{m}^{3}$. The main goal of this article was to make a forecast of gas production from domestic deposits based on the Balance of mine resources in Poland published by the Polish Geological Institute National Research Institute. The forecast of gas extraction from domestic deposits was made for the years 2020-2030. The production forecast was prepared for each gas-bearing region separately. In order to adjust the reported volumes to the applicable energy units, the gas production forecast for the Lowland fields was converted into high-methane gas production.

Key words: natural gas, gas production, natural gas reserves, forecast, gas fields.

\section{Regiony Polski zasobne w gaz ziemny}

Analiza została wykonana na podstawie danych publikowanych przez PIG - BIP w Bilansie zasobów zlóż i kopalin $w$ Polsce. Dane te prezentują zasoby wydobywalne, które przedstawione są w normalnych metrach sześciennych, więc nie uwzględniają rzeczywistej kaloryczności gazu ziemnego wydobywanego z różnych złóż. Zgodnie z publikacjami PIG - BIP stan zasobów w roku $2018\left(139,9 \mathrm{mld} \mathrm{m}^{3}\right)$ był prawie taki sam jak stan zasobów w roku 2007 (138,8 $\left.\mathrm{mld} \mathrm{m}^{3}\right)$, pomimo sumarycznego wydobycia gazu $\mathrm{w}$ analizowanym okresie wynoszącego $64,1 \mathrm{mld} \mathrm{m}^{3}$ (tab. 1). W bilansie ujęto również zasoby gazu występujące w podziemnych magazynach gazu, zakwalifikowane jako bufor wydobywalny. W poszczególnych magazynach wielkość buforu wydobywalnego wy-

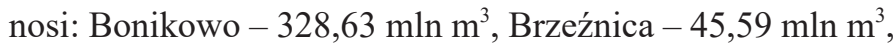
Daszewo - 27,72 $\mathrm{mln} \mathrm{m}^{3}$, Husów - 372,88 $\mathrm{mln} \mathrm{m}^{3}$, Strachocina - 121,5 $\mathrm{mln} \mathrm{m}^{3}$, Swarzów - 28,8 $\mathrm{mln}^{3}$ i Wierzchowice $5728,12 \mathrm{mln} \mathrm{m}^{3}$. Łączne zasoby gazu występujące w buforach PMG wynoszą 6,65 mld m³ (Szuflicki et al., 2020). Analizując bilans, można stwierdzić, że wszelkie inwestycje związane $\mathrm{z}$ udostępnieniem nowych zasobów prowadzone w latach 2007-2018 przyczyniły się do podtrzymania wielkości zasobów (Gientki et al., 2008; Wołkowicz et al., 2009, 2010; Szuflicki et al., 2011, 2012, 2013, 2014, 2015, 2016, 2017,
2018, 2019). W związku z tym dalsze podtrzymanie wielkości zasobów wydobywalnych będzie również wymagało znaczących inwestycji, co ma odzwierciedlenie w najbliższych planach inwestycyjnych PGNiG SA (PGNiG, 2019).

\section{Występowanie zasobów gazu ziemnego w złożach zlokalizowanych na Niżu Polskim}

Zgodnie z bilansem zasobów w roku 2018 na Niżu Polskim zlokalizowane były 153 złoża, których sumaryczne zasoby wydobywalne wynosiły 100,84 $\mathrm{mld} \mathrm{m}^{3}$ gazu. W roku 2018 na Niżu eksploatowanych było 78 złóż, o łącznych zasobach wydobywalnych wynoszących $48,49 \mathrm{mld}^{3}$. Natomiast wielkość zasobów przemysłowych eksploatowanych złóż wynosiła $32,56 \mathrm{mld} \mathrm{m}^{3}$. Histogram rozkładu wielkości rocznego wydobycia gazu ze złóż występujących na Niżu Polskim przedstawiono na rysunku 1. Na wykresie można zauważyć, że 60 złóż (z 78 eksploatowanych) posiadało zasoby mieszczące się w przedziale $0-500 \mathrm{mln} \mathrm{m}^{3}$. W związku z tym zasoby pozostałych 18 złóż były wyższe od $500 \mathrm{mln} \mathrm{m}^{3}$. W 2018 roku najwyższe zasoby ze wszystkich złóż eksploatowanych, wynoszące $13,7 \mathrm{mld} \mathrm{m}^{3}$, posiadało złoże Brońsko. Przedstawiony wykres pokazuje, że 31 złóż spośród 78 eksploatowanych w 2018 roku posiadało zasoby wydobywalne nie większe niż $50 \mathrm{mln} \mathrm{m}^{3}$.

Tabela 1. Zestawienie zasobów i wydobycia gazu ziemnego w geologicznych regionach Polski

Table 1. Natural gas resources and gas production in geological regions of Poland

\begin{tabular}{|c|c|c|c|c|}
\hline \multirow[t]{2}{*}{ Region geologiczny } & $\begin{array}{l}\text { Zasoby wydobywalne } \\
\text { w } 2007 \text { r. }\end{array}$ & $\begin{array}{c}\text { Zasoby wydobywalne } \\
\text { w } 2018 \text { r. }\end{array}$ & $\begin{array}{l}\text { Wydobycie } \\
2007-2018\end{array}$ & $\begin{array}{l}\text { Wydobycie } \\
\text { w } 2018 \text { r. }\end{array}$ \\
\hline & \multicolumn{4}{|c|}{$\left[\mathrm{mln} \mathbf{~ m}^{3}\right]$} \\
\hline Kraj & 138822,40 & 139929,31 & 64057,95 & 4926,05 \\
\hline Bałtyk & 4875,32 & 4846,40 & 460,83 & 23,25 \\
\hline Karpaty & 1295,22 & 1374,87 & 387,56 & 31,45 \\
\hline Niż Polski & 91859,64 & 100840,93 & 44344,81 & 3584,91 \\
\hline Przedgórze Karpat & 40792,22 & 32867,11 & 18864,75 & 1286,45 \\
\hline
\end{tabular}

Wartości przeliczone na gaz wysokometanowy, współczynnik przeliczenia wzięty z http://pgnig.pl/documents/10184/2580770/ PGNiG_w_liczbach_2018.pdf 


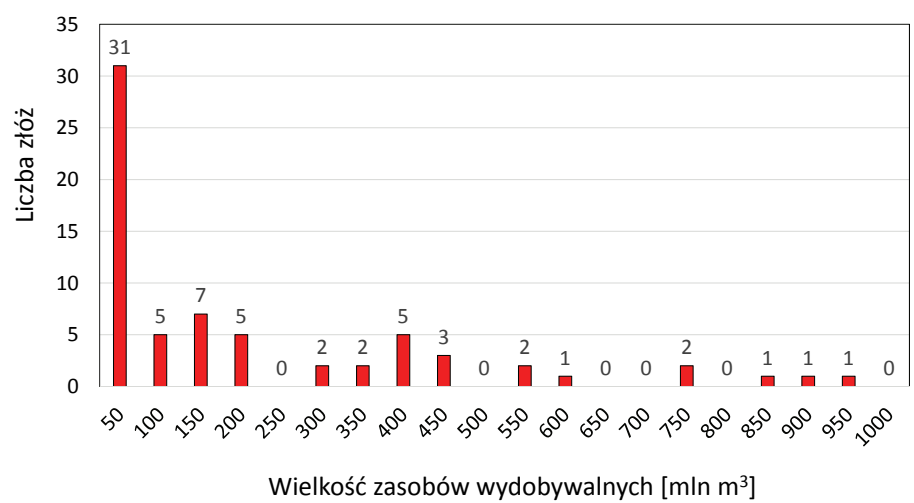

Rys. 1. Histogram wielkości zasobów wydobywalnych - Niż Polski, stan na 2018 rok

Fig. 1. Histogram of recoverable resources, Polish Lowlands, as at the end of 2018

\section{Występowanie zasobów gazu ziemnego w złożach zlokalizowanych na przedgórzu Karpat}

Bilans zasobów z roku 2018 wykazywał, że na przedgórzu Karpat występowało 105 złóż, których zasoby wydobywalne wynosiły $32,87 \mathrm{mld}^{3}$ gazu, a wielkość ich zasobów przemysłowych była równa $8,56 \mathrm{mld} \mathrm{m}^{3}$. W roku $2018 \mathrm{w}$ eksploatacji było 77 złóż, o zasobach wydobywalnych wynoszących $29,29 \mathrm{mld} \mathrm{m}^{3}$. Natomiast wielkość zasobów przemysłowych złóż eksploatowanych wynosiła $6,67 \mathrm{mld}^{3}$. Histogram rozkładu wielkości zasobów wydobywalnych złóż na Przedgórzu przedstawiono na rysunku 2. Na wykresie można zauważyć, że 64 złoża (spośród wszystkich 77 złóż) posiadają zasoby wydobywalne mieszczące się w przedziale $0-500 \mathrm{mln} \mathrm{m}^{3}$. Największe złoże występujące na Przedgórzu, złoże gazu ziemnego Przemyśl, posiadało zasoby wydobywalne wynoszące $7,46 \mathrm{mld} \mathrm{m}^{3}$. Dodatkowo przedstawiony na wykresie rozkład wielkości zasobów wydobywalnych pokazuje, że w 2018 roku zasoby 21 złóż zawierały się w przedziale $0-50 \mathrm{mln} \mathrm{m}^{3}$.

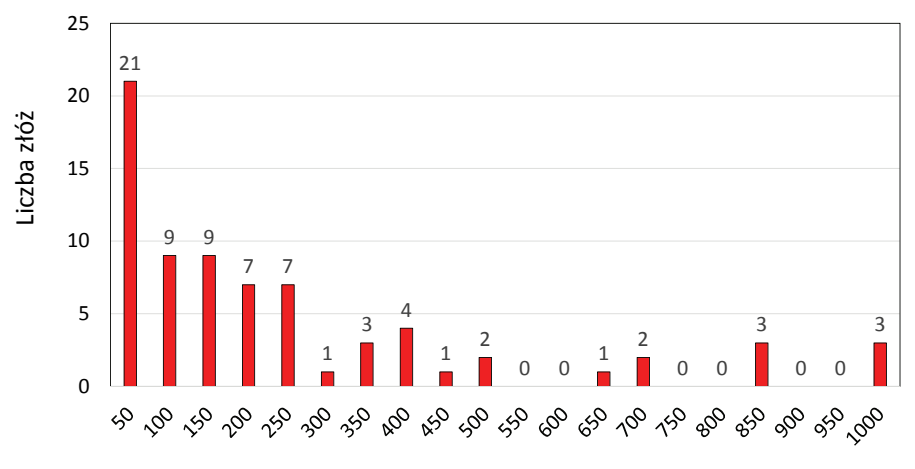

Wielkość zasobów wydobywalnych $\left[\mathrm{m} / \mathrm{n} \mathrm{m}^{3}\right.$ ]

Rys. 2. Histogram wielkości zasobów wydobywalnych - przedgórze Karpat, stan na 2018 rok

Fig. 2. Histogram of recoverable resources, Carpathian Foreland, as at the end of 2018

\section{Występowanie zasobów gazu ziemnego w złożach zlokalizowanych w Karpatach}

Zgodnie z bilansem zasobów z roku 2018 w Karpatach występowało 35 złóż, których sumaryczne zasoby wydobywalne wynosiły $1,37 \mathrm{mld}^{3}$ gazu, a suma zasobów przemysłowych była równa $0,31 \mathrm{mld} \mathrm{m}^{3}$. W roku $2018 \mathrm{w}$ trakcie eksploatacji było 25 złóż, o zasobach wydobywalnych wynoszących $822,6 \mathrm{mln} \mathrm{m}^{3}$. Natomiast wielkość zasobów przemysłowych tych złóż wynosiła $185,81 \mathrm{mln} \mathrm{m}^{3}$. Histogram rozkładu wielkości zasobów wydobywalnych złóż w Karpatach przedstawiono na rysunku 3. Na wykresie można zauważyć, że 16 złóż (spośród wszystkich 35) posiada zasoby wydobywalne mieszczące się w przedziale $0-20 \mathrm{mln}^{3}$, a największe złoże gazu ziemnego, Jaszczew, posiadało zasoby wydobywalne wynoszące $201,9 \mathrm{mln}^{3}$.

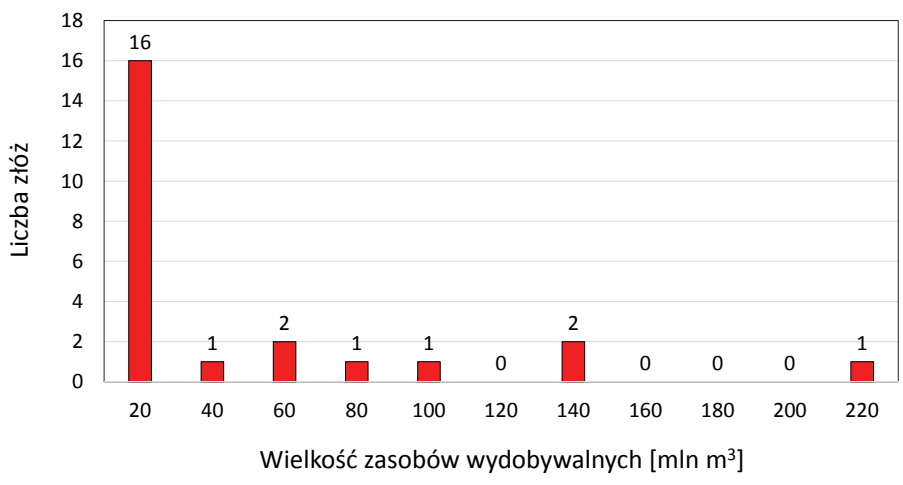

Rys. 3. Histogram wielkości zasobów wydobywalnych - Karpaty, stan na 2018 rok

Fig. 3. Histogram of recoverable resources, Carpathians, as at the end of 2018

\section{Występowanie zasobów gazu ziemnego w złożach zlokalizowanych w polskiej strefie Bałtyku}

Zgodnie z bilansem zasobów z roku 2018 w polskiej strefie Bałtyku występowało 5 złóż, których sumaryczne zasoby wydobywalne wynosiły $4,85 \mathrm{mld}^{3}$ gazu. Histogram rozkładu wielkości zasobów złóż występujących w strefie Bałtyku przedstawiono na rysunku 4. Na wykresie można zauważyć, że na koniec roku 2018 dwa złoża posiadały zasoby wydobywalne mieszczące się $\mathrm{w}$ przedziale $200-400 \mathrm{mln} \mathrm{m}^{3}$ (B21 - $275 \mathrm{mln} \mathrm{m}^{3}$ i B3 - $224 \mathrm{mln} \mathrm{m}^{3}$ ). Pozostałe złoża miały zasoby wynoszące: B8 - $541 \mathrm{mln} \mathrm{m}^{3}$, B4 - $2014 \mathrm{mln} \mathrm{m}^{3}$ i B6 - $1793 \mathrm{mln} \mathrm{m}^{3}$ (rys. 4). Największe zasoby wydobywalne posiadało złoże B4. Niestety złoża B4, B21, B6 nie były eksploatowane w 2018 roku. W roku 2018 w trakcie eksploatacji były dwa złoża, B3 i B8, o sumarycznych zasobach wydobywalnych wynoszących $764,4 \mathrm{mln} \mathrm{m}^{3}$. Natomiast suma zasobów przemysłowych tych złóż była równa $681,3 \mathrm{mln} \mathrm{m}^{3}$. 


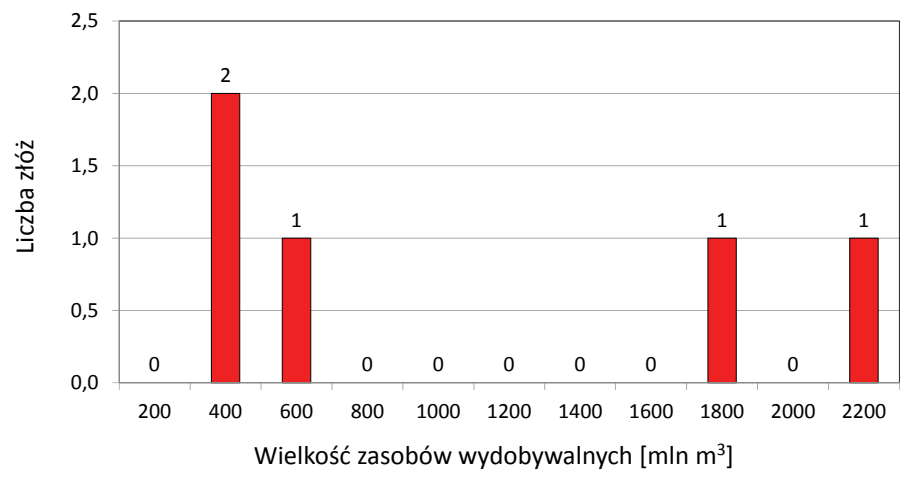

Rys. 4. Histogram wielkości zasobów wydobywalnych - rejon Bałtyku, stan na 2018 rok

Fig. 4. Histogram of recoverable resources, Baltic region, as at the end of 2018

\section{Założenia przyjęte do wykonania prognoz dalszej eksploatacji krajowych złóż gazu ziemnego}

W bilansie przedstawionym na koniec roku 2018 zostało wykazanych 298 złóż, z czego 182 złoża były w eksploatacji. Z tej liczby 78 złóż znajdowało się na Niżu, 77 złóż - na przedgórzu Karpat, 25 złóż - w Karpatach i 2 złoża - w strefie Bałtyku. Autorzy zdecydowali o wykonaniu prognozy wydobycia dla aktualnie eksploatowanych złóż, gdyż trudno jest przewidzieć, kiedy i jakie złoża w przyszłości zostaną włączone do eksploatacji. Jednym słowem prognoza ma odzwierciedlać aktualny potencjał wydobywczy. Należy podkreślić, że włączenie nowych złóż do eksploatacji wymaga znacznych inwestycji finansowych w poszukiwania i zagospodarowanie.

Autorzy publikacji zdecydowali, że prognozę wydobycia gazu ze złóż wykonają dla każdego rejonu oddzielnie. Prognoza wydobycia gazu ze złóż krajowych została przygotowana na podstawie dwóch metod:

- analizy sumarycznego wydobycia gazu ze wszystkich złóż dla całego rejonu (analiza całościowa);

- analizy wydobycia gazu z największych złóż danego rejonu (analiza indywidualna).

Prognoza całościowa została wykonana przy założeniu, że cały analizowany rejon traktowany jest jako jedno duże złoże, którego roczne wydobycie stanowi sumę wydobycia gazu z wszystkich eksploatowanych w danym rejonie złóż. Prognozy wydobycia gazu w przypadku analizy indywidualnej zostały wykonane dla wybranych największych złóż danego rejonu. Natomiast pozostałe złoża $\mathrm{z}$ analizowanego rejonu zostały potraktowane jako jedno duże złoże o sumarycznym wydobyciu. Opracowanie listy największych złóż, które zostały poddane analizie indywidualnej, wymagało wykonania histogramu wydobycia gazu uwzględniającego wszystkie złoża eksploatowane w Polsce w roku 2018 (rys. 5). Analizując przedstawiony histogram, można zauważyć, że roczna wielkość wydobycia gazu z każdego ze 164 złóż (182 w eksploatacji) nie przekraczała $50 \mathrm{mln} \mathrm{m}^{3}$. Dodatkowo należy podkreślić, że w 2018 roku wydobycie ze 100 złóż nie przekraczało $5 \mathrm{mln} \mathrm{m}^{3} /$ rok. Szczegółowa analiza 100 złóż z rocznym wydobyciem gazu nieprzekraczającym wielkości $5 \mathrm{mln}^{3}$ wykazała, że wydobycie z 58 złóż było nie większe niż $1 \mathrm{mln} \mathrm{m}^{3} /$ rok.

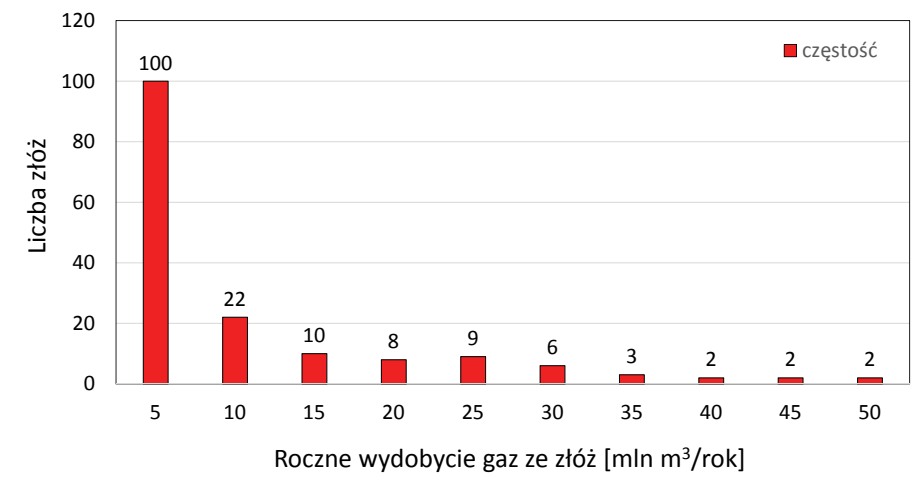

Rys. 5 Histogram wielkości rocznego wydobycia gazu ze złóż w Polsce, stan na 2018 rok

Fig. 5. Histogram of the annual gas production from fields in Poland, as at the end of 2018

Tabela 2. Lista złóż wybranych do analizy indywidualnej

Table 2. List of gas fields selected for individual analysis

\begin{tabular}{|c|c|c|}
\hline $\mathbf{N r}$ & Zloże & $\begin{array}{c}\text { Wydobycie gazu } \\
{\left[\mathrm{mln} \mathrm{\textrm {m } ^ { 3 } ]}\right.}\end{array}$ \\
\hline \multicolumn{3}{|c|}{ Niż Polski } \\
\hline 1 & BMB (Barnówko-Mostno-Buszewo) & 392,50 \\
\hline 2 & Bogdaj-Uciechów & 78,53 \\
\hline 3 & Brońsko & 904,63 \\
\hline 4 & Grochowice & 48,13 \\
\hline 5 & Jabłonna & 50,18 \\
\hline 6 & Kościan S & 319,23 \\
\hline 7 & Lubiatów & 232,71 \\
\hline 8 & Międzychód & 49,20 \\
\hline 9 & Paproć & 250,24 \\
\hline 10 & Paproć W & 119,95 \\
\hline 11 & Radlin & 118,85 \\
\hline 12 & Wielichowo & 94,22 \\
\hline 13 & Wilków & 82,94 \\
\hline 14 & Załęcze & 90,35 \\
\hline 15 & Żuchlów & 171,33 \\
\hline \multicolumn{3}{|c|}{ Przedgórze Karpat } \\
\hline 1 & Dzików & 66,17 \\
\hline 2 & Kielanówka-Rzeszów & 52,98 \\
\hline 3 & Mirocin & 44,53 \\
\hline 4 & Pruchnik-Pantalowice & 50,92 \\
\hline 5 & Przemyśl & 435,7 \\
\hline 6 & Przeworsk & 41,17 \\
\hline 7 & Zalesie & 142,67 \\
\hline
\end{tabular}


Przeprowadzona analiza wykazała, że roczne wydobycie gazu z 22 eksploatowanych złóż w Polsce przekracza $40 \mathrm{mln} \mathrm{m}^{3}$. W związku z tym autorzy zdecydowali się na wykonanie szczegółowej prognozy wydobycia gazu dla złóż, z których roczne wydobycie gazu w 2018 roku przekroczyło $40 \mathrm{mln} \mathrm{m}^{3}$. W tabeli 2 pokazano listę wszystkich 22 złóż wybranych do analizy indywidualnej.

Wszystkie prognozy wydobycia gazu ze złóż zostały wykonane dla lat 2019-2030. Analizę całościową przygotowano dla każdego rejonu oddzielnie. Każda prognoza wydobycia gazu powstała na podstawie wielkości wydobycia gazu raportowanych w latach 2007-2018. Prognozę wydobycia gazu można wykonać przy zastosowaniu różnych modeli matematycznych (Paliński, 2019). W analizie przygotowanej na potrzeby bieżącej publikacji wykorzystano krzywe dotychczasowego wydobycia. Przykład analizy całościowej przedstawiono na rysunku 6 , który prezentuje wydobycie gazu ze wszystkich złóż Niżu dla lat 2012-2018 wraz z prognozą wydobycia dla lat 2019-2030. Na wykresie można zauważyć, że wydobycie gazu w okresie 2012-2018 układa się w jednoznaczną linię trendu. Należy podkreślić, że praktycznie wszystkie złoża gazu ziemnego w Polsce są w końcowej fazie wydobycia, gdyż eksploatowane są od lat siedemdziesiątych (lub wcześniej) ubiegłego wieku, a ich aktualne ciśnienia złożowe rzadko przekraczają 2-3 MPa. W związku z tym roczny spadek wydobycia gazu z złóż ma charakter praktycznie linowy. Prognoza dalszego wydobycia gazu ze złóż krajowych dla lat 2019-2030 jest zgodna z wcześniejszą linią trendu.

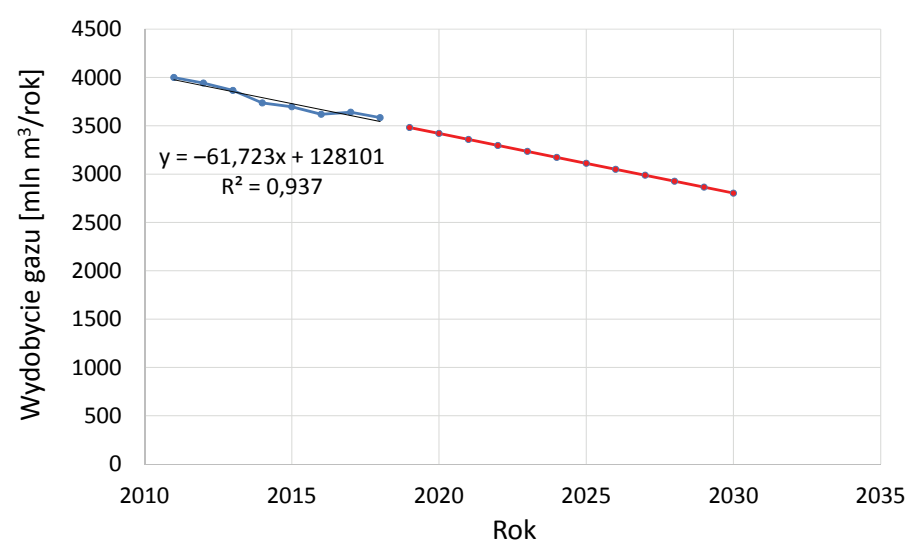

$\rightarrow$ Qwyd [mln $\left.\mathrm{m}^{3} / \mathrm{rok}\right] \rightarrow-$ Qprog [m/n $\left.\mathrm{m}^{3} / \mathrm{rok}\right]$ —Liniowy (Qwyd [m/n $\left.\mathrm{m}^{3} / \mathrm{rok}\right]$ )

Rys. 6. Niż Polski - wykres wydobycia gazu do roku 2018 oraz prognoza wydobycia do 2030

Fig. 6. Polish Lowland, gas production until 2018 and gas production forecast until 2030

Analiza indywidualna polegała na wykonaniu indywidualnej prognozy wydobycia gazu dla każdego dużego złoża przedstawionego $\mathrm{w}$ tabeli 2 . Zasada przygotowania prognozy była identyczna jak w przypadku prognozy całościowej. Przykładem prognozy indywidualnej jest prognoza dla złoża Kielanówka-Rzeszów (rys. 7). Pozostałe „małe” złoża danego rejonu zostały potraktowane jako jedno złoże, dla którego wykonano prognozę wydobycia gazu do roku 2030. Prognozę wydobycia gazu z „małych” złóż przygotowano przy założeniu braku odkryć nowych zasobów. Rysunek 8 prezentuje prognozę wydobycia gazu z „małych” złóż przedgórza Karpat. Prognoza wydobycia gazu dla danego rejonu jest sumą prognoz wykonanych dla dużych i małych złóż.

Należy podkreślić, że prognozy mają charakter szacunkowy, gdyż zostały wykonane na bazie ogólnych danych. Przygotowanie precyzyjnej prognozy wymaga przeprowadzenia analizy szczegółowych danych eksploatacyjnych.

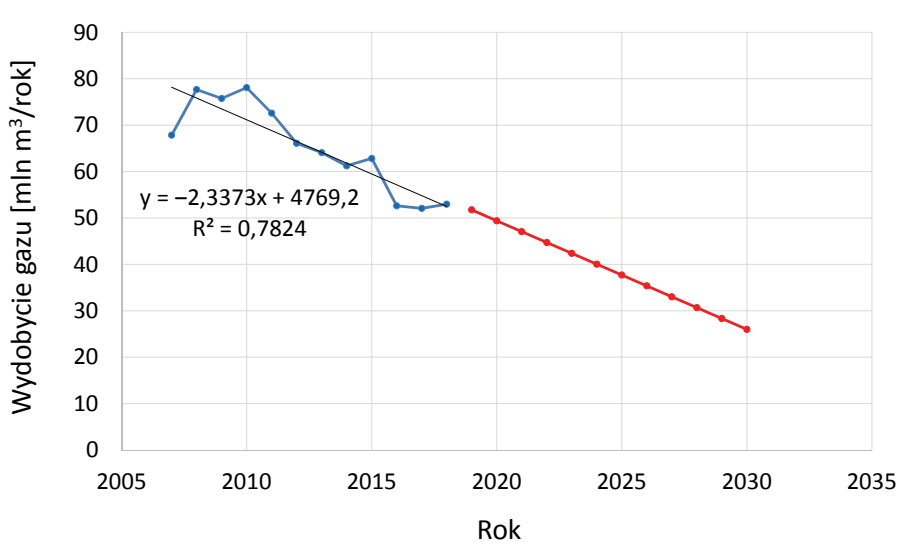

$\rightarrow$ Qwyd [mln $\left.\mathrm{m}^{3} / \mathrm{rok}\right] \rightarrow$ Qprog [mln $\left.\mathrm{m}^{3} / \mathrm{rok}\right]$ - Liniowy (Qwyd [m/n $\left.\mathrm{m}^{3} / \mathrm{rok}\right]$ )

Rys. 7. Złoże gazu ziemnego Kielanówka-Rzeszów - wykres wydobycia gazu do roku 2018 oraz prognoza wydobycia gazu do roku 2030

Fig. 7. The Kielanówka-Rzeszów natural gas field, gas production until 2018 and gas production forecasts until 2030

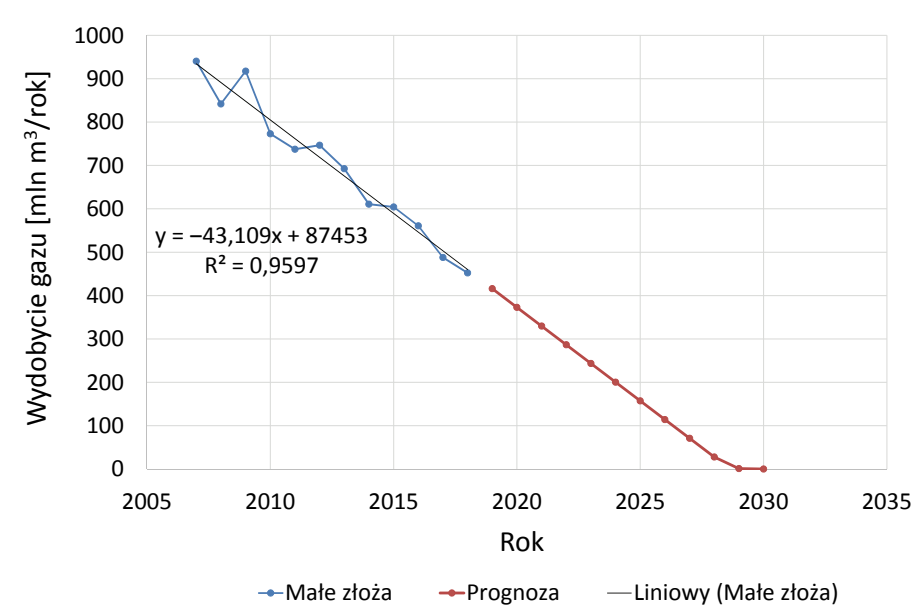

Rys. 8. Małe złoża gazu ziemnego przedgórza Karpat - wykres wydobycia gazu do roku 2018 oraz prognoza wydobycia gazu do roku 2030

Fig. 8. Small natural gas fields in the Carpathian Foreland, gas production until 2018 and gas production forecast until 2030 


\section{Prognoza wydobycia gazu ze złóż krajowych wykonana dla okresu 2019-2030}

Roczne krajowe wydobycie gazu w latach 1995-2018 zmieniało się w przedziale 3,6-4,3 $\mathrm{mld} \mathrm{m}^{3}$ (Filar et al., 2020). Prognozy wydobycia opracowane dla złóż i rejonów zostały wykonane na podstawie danych wydobycia gazu rodzimego. W związku z tym, że prognozy wydobycia krajowego powstają na bazie gazu wysokometanowego, to prognozę wydobycia gazu ze złóż Niżu przeliczono na gaz wysokometanowy. Współczynnik przeliczenia został zaczerpnięty z danych publikowanych na stronie internetowej PGNiG SA. Rysunek 9 przedstawia prognozę wydobycia gazu wysokometanowego dla całej Polski. Jak już wcześniej stwierdzono, prognoza została wykonana dla dwóch wariantów: analizy całościowej oraz analizy indywidualnej. Można zauważyć, że różnica w prognozie wydobycia gazu pomiędzy wariantami wynosi około $1 \mathrm{mld} \mathrm{m}^{3}$ (rok 2030). Główną przyczyną tej sytuacji jest to, że prognoza całościowa uwzględnia wszystkie inwestycje prowadzone w latach 2007-2018, których celem było włączanie do eksploatacji nowych odwiertów i złóż. Można stwierdzić, że przeprowadzone inwestycje pozwoliły na podtrzymanie wielkości wydobycia gazu ziemnego ze złóż krajowych. Natomiast prognoza indywidualna zakładała brak inwestycji pozwalających na eksploatację nowych zasobów. Prognoza wydobycia gazu w Polsce wykonana dla wariantu inwestycyjnego (całościowego) pokazuje, że w przypadku utrzymania poziomu inwestycji wydobycie gazu z krajowych złóż spadnie z 3,9 mld $\mathrm{m}^{3}$ (2018) do 2,8 $\mathrm{mld} \mathrm{m}^{3}$ (2030). Natomiast prognoza wydobycia gazu w Polsce przygotowana dla wariantu braku inwestycji wykazała, że wydobycie gazu spadnie z $3,9 \mathrm{mld} \mathrm{m}^{3}$ (2018) do $1,8 \mathrm{mld}^{3}$ (2030). Prawdopodobnie rzeczywiste krajowe

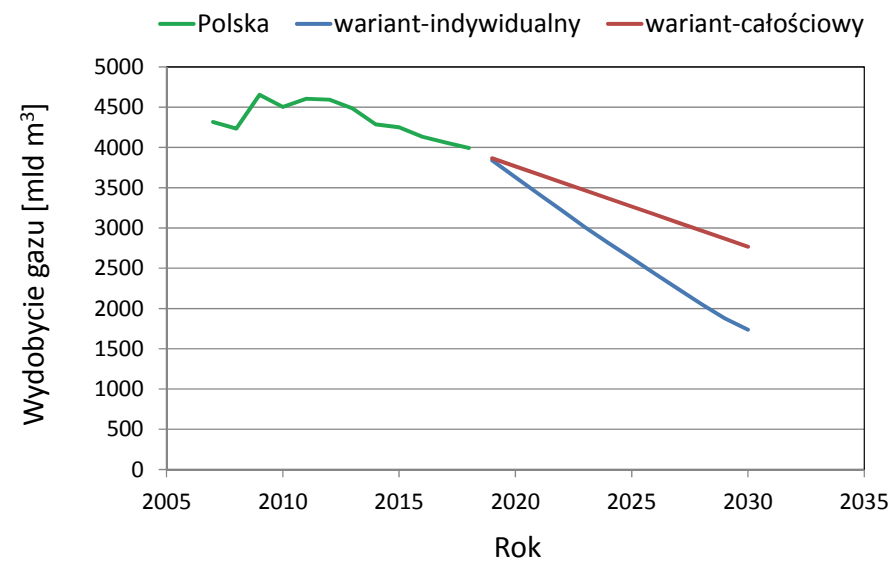

Rys. 9. Wydobycie gazu wysokometanowego w Polsce oraz prognoza wydobycia gazu ziemnego ze złóż w Polsce wykonana dla wariantu „całościowego" oraz ,indywidualnego"

Fig. 9. Gas production in Poland and forecast of natural gas production from deposits in Poland, made for the „comprehensive” and "individual" variants wydobycie gazu będzie oscylować pomiędzy tymi dwiema prognozami, w zależności od poziomu przyszłych inwestycji. Należy pamiętać o tym, że inwestycje w krajowe wydobycie gazu zwiększają bezpieczeństwo energetyczne Polski (Rychlicki i Siemek, 2007; Janusz, 2010).

\section{Podsumowanie i wnioski}

Głównym celem publikacji było przedstawienie szacunkowej prognozy wydobycia gazu ze złóż krajowych, opracowanej na podstawie publikowanego przez Państwowy Instytut Geologiczny - Państwowy Instytut Badawczy Bilansu zasobów złóż kopalin w Polsce. Prognozę wydobycia gazu z krajowych złóż wykonano dla lat 2019-2030. W 2018 roku stan zasobów wydobywalnych gazu ziemnego w Polsce wynosił $139,93 \mathrm{mld} \mathrm{m}^{3}$, natomiast zasoby przemysłowe złóż gazu ziemnego były równe $66,64 \mathrm{mld}^{3}$. W bilansie przedstawionym na koniec roku 2018 zostało wykazanych 298 złóż, z czego eksploatowane w roku 2018 były 182 złoża. Autorzy publikacji wykonali prognozę wydobycia gazu ze złóż krajowych dwiema metodami: jedną uwzględniającą inwestycje w dotychczasowe zdolności wydobywcze, drugą zakładającą brak takich inwestycji. Prognoza wydobycia gazu w Polsce dla wariantu inwestycyjnego (całościowego) pokazała, że w przypadku utrzymania poziomu inwestycji wydobycie gazu z krajowych złóż spadnie z 3,9 mld m³ (2018) do 2,8 $\mathrm{mld} \mathrm{m}^{3}$ (2030). Natomiast zgodnie z prognozą wydobycia gazu w Polsce dla wariantu braku inwestycji wydobycie gazu spadnie z $3,9 \mathrm{mld} \mathrm{m}^{3}$ (2018) do $1,8 \mathrm{mld} \mathrm{m}^{3}$ (2030). Rzeczywiste krajowe wydobycie gazu będzie oscylować pomiędzy tymi dwiema prognozami, w zależności od poziomu przyszłych inwestycji. Wykonane badania wykazały, że w związku z prognozowanym spadkiem krajowego wydobycia gazu rosnące zużycie gazu będzie zaspokajane rosnącym importem (Kaliski et al., 2010).

Wykonana analiza pozwala na stwierdzenie, że prawdopodobnie prognozowana wielkość wydobycia gazu w Polsce w roku 2030 będzie zawierać się w przedziale 2,8-1,8 $\mathrm{mld} \mathrm{m}^{3}$ i będzie zależeć od wielkości nakładów inwestycyjnych przeznaczonych na poszukiwanie i zagospodarowanie nowych zasobów gazu ziemnego. W związku z tym, że analiza rocznego wydobycia gazu wykazała, że wydobycie z 58 złóż nie przekroczyło $1 \mathrm{mln} \mathrm{m}^{3} /$ rok, to w najbliższym czasie należy oczekiwać likwidacji dużej liczby złóż. Likwidacja każdego złoża powinna zostać poprzedzona szczegółową analizą możliwości wykorzystania odwiertów oraz złóż do innych celów, takich jak zatłaczanie $\mathrm{CO}_{2}$, pompy ciepła, geotermia lub inne.

Artykuł powstał na podstawie pracy statutowej pt. Prognoza wydobycia gazu z złóz krajowych w oparciu o analize bilansowa 
aktualnego stanu zasobów gazu ziemnego wykonana dla okresu 2020-2030 - praca INiG - PIB na zlecenie MNiSW; nr zlecenia: 0063/KP/2020, nr archiwalny: DK-4100-0051/2020.

\section{Literatura}

Filar B., Miziołek M., Kwilosz T., 2020. Dostosowanie parametrów pracy PMG do aktualnych potrzeb rynku gazu ziemnego w Polsce. Nafta-Gaz, 9: 601-609. DOI: 10.18668/NG.2020.09.06.

Gientki M., Malon A., Dyląg J., 2008. Bilans zasobów złóż kopalin W Polsce wg stanu na 31.XII.2007 r. <http://geoportal.pgi.gov. $\mathrm{pl} />$ (dostęp: 11.02.2020).

Janusz P., 2010. Zasoby gazu ziemnego w Polsce jako czynnik poprawiający bezpieczeństwo energetyczne, na tle wybranych państw UE. Polityka Energetyczna, 13(1): 23-41.

Kaliski M., Nagy S., Rychlicki S., Siemek J., Szurlej A., 2010. Gaz ziemny w Polsce - wydobycie, zużycie i import do 2030 roku. Górnictwo i Geologia, 5(3): 27-40.

Paliński A., 2019. Prognozowanie zapotrzebowania na gaz metodami sztucznej inteligencji. Nafta-Gaz, 2: 111-117. DOI: 10.18668/ NG.2019.02.07.

PGNiG, 2019. Stabilny wzrost wydobycia gazu ziemnego i ropy naftowej. <http://pgnig.pl/aktualnosci/-/news-list/id/stabilnywzrost-wydobycia-gazu-ziemnego-i-ropy-naftowej/newsGroupId/10184> (dostęp: 11.02.2020).

Rychlicki S., Siemek J., 2007. Gaz ziemny w strategii bezpieczeństwa energetycznego Polski i jego szanse w Europie. Polityka Energetyczna, 10(1): 47-70.

Szuflicki M., Malon A., Tymiński M., 2011. Bilans zasobów złóż kopalin w Polsce wg stanu na 31.XII.2010 r. < http://geoportal.pgi. gov.pl/> (dostęp: 11.02.2020).

Szuflicki M., Malon A., Tymiński M., 2012. Bilans zasobów złóż kopalin w Polsce wg stanu na 31.XII.2011 r. <http://geoportal.pgi. gov.pl/> (dostęp: 11.02.2020).

Szuflicki M., Malon A., Tymiński M., 2013. Bilans zasobów złóż kopalin w Polsce wg stanu na 31.XII.2012 r. <http://geoportal.pgi. gov.pl/> (dostęp: 11.02.2020).

Szuflicki M., Malon A., Tymiński M., 2014. Bilans zasobów złóż kopalin w Polsce wg stanu na 31.XII.2013 r. <http://geoportal.pgi. gov.pl/> (dostęp: 11.02.2020).

Szuflicki M., Malon A., Tymiński M., 2015. Bilans zasobów złóż kopalin w Polsce wg stanu na 31.XII.2014 r. <http://geoportal.pgi. gov.pl/> (dostęp: 11.02.2020)
Szuflicki M., Malon A., Tymiński M., 2016. Bilans zasobów złóż kopalin w Polsce wg stanu na 31.XII.2015 r. < http://geoportal.pgi. gov.pl/> (dostęp: 11.02.2020).

Szuflicki M., Malon A., Tymiński M., 2017. Bilans zasobów złóż kopalin w Polsce wg stanu na 31.XII.2016 r. <http://geoportal.pgi. gov.pl/> (dostęp: 11.02.2020).

Szuflicki M., Malon A., Tymiński M., 2018. Bilans zasobów złóż kopalin w Polsce wg stanu na 31.XII.2017 r. <http://geoportal.pgi. gov.pl/> (dostęp: 11.02.2020).

Szuflicki M., Malon A., Tymiński M., 2019. Bilans zasobów złóż kopalin w Polsce wg stanu na 31.XII.2018 r. <http://geoportal.pgi. gov.pl/> (dostęp: 11.02.2020).

Szuflicki M., Malon A., Tymiński M., 2020. Bilans zasobów złóż kopalin w Polsce wg stanu na 31.XII.2019 r. < http://geoportal.pgi. gov.pl/> (dostęp: 11.02.2020).

Wołkowicz S., Malon A., Tymiński M., 2009. Bilans zasobów złóż kopalin w Polsce wg stanu na 31.XII.2008 r. <http://geoportal. pgi.gov.pl/> (dostęp: 11.02.2020).

Wołkowicz S., Malon A., Tymiński M., 2010. Bilans zasobów złóż kopalin w Polsce wg stanu na 31.XII.2009 r. <http://geoportal. pgi.gov.pl/> (dostęp: 11.02.2020).

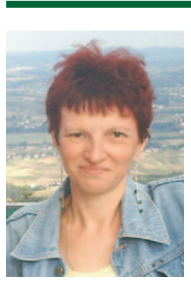

Mgr inż. Wacława PIESIK-BUŚ

Starszy specjalista badawczo-techniczny w Zakładzie Podziemnego Magazynowania Gazu Instytut Nafty i Gazu - Państwowy Instytut Badawczy ul. Lubicz 25 A

31-503 Kraków

E-mail: piesik@inig.pl

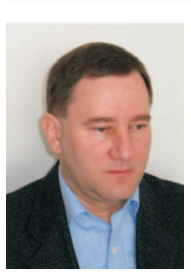

Mgr inż. Bogdan FILAR

Kierownik Zakładu Podziemnego

Magazynowania Gazu

Instytut Nafty i Gazu - Państwowy Instytut Badawczy ul. Lubicz $25 \mathrm{~A}$

31-503 Kraków

E-mail: bogdan.filar@inig.pl 